\title{
Antiproliferative activities of Althaea ludwigii L. extract on Michigan Cancer Foundation-7 breast cancer cell line
}

\author{
Zinah Essam Hameed Alshaya ${ }^{1}$, Enas Jawad Kadhim ${ }^{1}$, Hayder B. Sahib ${ }^{2 *}$ \\ ${ }^{1}$ Department of Pharmacognosy, College of Pharmacy, University of Baghdad, Baghdad, Iraq, ${ }^{2}$ Department of Pharmacology, College of Pharmacy, Al-Nahrain \\ University, Baghdad, Iraq
}

\section{ARTICLE INFO}

Article history:

Received on: September 21, 2018

Accepted on: December 01, 2018

Available online: April 05, 2019

\section{Key words:}

Cytotoxicity,

Cellular viability,

Plant extract,

Flavonoids,

Breast cancer

\begin{abstract}
Cancer has been considered one of these major community healthiness problems. Althaea ludwigii L. (family: Malvaceae) is an indigenous plant, widely distributed in Iraq. The objective of this study is to explore the antiproliferative action of A. ludwigii L. against breast cancer cell line Michigan Cancer Foundation-7 (MCF-7) and rate embryonic fibroblasts (REF) normal cell line and to identify the bioactive constituent. The aerial parts of $A$. ludwigii L. were grinded into fine powder then extracted with $85 \%$ methanol. Methanol extract was further partitioned with ethyl acetate. Ethyl acetate fraction was chosen to test against MCF-7 by (3-[4, 5-dimethylthiazol-2-yl]-2, 5 (MTT assay) the bioactive constituents were investigated by high performance thin layer chromatography high-performance thin-layer chromatography (HPTLC). The data showed that ethyl acetate fraction has significant antiproliferative activity against MCF-7 $\left(\mathrm{IC}_{50}=35.5 \mu \mathrm{g} / \mathrm{ml}\right)$ and REF $\left(\mathrm{IC}_{50}=1762.9 \mu \mathrm{g} / \mathrm{ml}\right)$, HPTLC showed the existence of rutin in ethyl acetate fraction. The antiproliferative activity may relate to the existence of rutin which had been approved as potent anticancer.
\end{abstract}

\section{INTRODUCTION}

For many years, medicinal plants had been the only method for the treatment of several ethnic groups; now, traditional medicinal plants are still used to treat or to act as prophylaxis against many diseases [1]. Many countries around the world use medicinal plants constituent as a common alternative for cancer prevention and treatment [2,3]. $60 \%$ of the anticancer drugs have been extracted from natural products; more than 3000 plants worldwide have been reported to possess anticancer properties [4]. Throughout history, plant extracts and their purified active components have been the backbone of cancer chemotherapeutics [5]. Cancer chemoprevention, by the use of natural, dietary, or synthetic agents that can reverse, suppress, or prevent carcinogenic progression, has become an appealing strategy to combat the dogma associated with increasing cases of cancers worldwide [6]. Various number of medicinal and poisonous plants grow in Iraq, which are mostly used for home remedies. Investigation of the active constituents of these plants might bring good credit for the drug industries; analysis of some wild drugs gave very satisfactory results [7]. Of these wildly grown and widely distributed plant species, Iraqi Althaea ludwigii L. (family: Malvaceae) was chosen for this study.

*Corresponding Author

Hayder B. Sahib,

Department of Pharmacognosy,

College of Pharmacy, University of Baghdad,

Baghdad, Iraq. H.P.: 00964-7812353838.

Email: haider_bahaa@yahoo.com

\section{MATERIALS AND METHODS}

\subsection{Plant Material}

A. ludwigii L. (Malvaceae) was harvested from Msayab city south of Baghdad. The plant was authenticated by the National Herbarium at Abu Ghraib. The plant was collected during the month of June (2017) and was rained with tap water, dried at room temperature in the shade, then pulverized by mechanical mills, the weight had been recorded.

\subsection{Extraction}

Shade-dried coarsely powdered aerial parts $(200 \mathrm{~g})$ were packed in a thimble of Soxhlet apparatus and extracted with $85 \%$ methanol until complete exhaustion. The alcoholic extract was filtered, and then, the solvent was evaporated under reduced pressure using the rotary evaporator at a $40^{\circ} \mathrm{C}$. The extract was further partitioned with ethyl acetate. The fraction was dried over anhydrous sulfate, filtered, and evaporated to dryness. The fraction was weighted and assigned for further analysis [8].

\subsection{Cell Cultures}

Michigan Cancer Foundation-7 (MCF-7) cell line and rate embryonic fibroblasts (REF) cell line obtained from the Iraq biotech Cell Bank Unit and were maintained in RPMI-1640 supplemented with $10 \%$ fetal bovine, 100 units $/ \mathrm{mL}$ penicillin, and $100 \mu \mathrm{g} / \mathrm{mL}$ streptomycin. Cells were incubated at $37^{\circ} \mathrm{C}$ and were [10]. 


\subsubsection{Cell viability assay}

The cell viability was evaluated by thiazolyl blue tetrazolium bromide (MTT) assay. Cells were seeded in 96-well plates at concentration of 1 $\times 10^{4} /$ well, passage 8 and incubated at $37^{\circ} \mathrm{C}$ for $24 \mathrm{~h}$. Then, MEOS was added by dissolving the fraction dimethyl sulfoxide (DMSO) and diluted the mixture with the medium to make the final DMSO concentration of $1 \%$ MEOS was incubated with the cells for $72 \mathrm{~h}$, and then, $20 \mu \mathrm{l}$ from 5 $\mathrm{mg} / \mathrm{mL}$ of MTT was added on each well and incubated for $5 \mathrm{~h}$, at $37^{\circ} \mathrm{C}$ and $5 \% \mathrm{CO}_{2}$. Then, medium was aspirated and $200 \mu \mathrm{l}$ from DMSO added to dissolve the formazon crystal that is formed. The spectrophotometric absorbance of the samples had been measured by the microplate readers, with a measurement wavelength of $570 \mathrm{~nm}$ and reference wavelength of $650 \mathrm{~nm}$. DMSO at 1\% was used as negative control and the results were presented as mean percent of inhibition to the negative control $\pm \mathrm{SD}$. Each experiment was performed in quadruplicatedifferent concentrations of the ethyl acetate fraction $(6.25,12.5,25,50$, and $100 \mu \mathrm{g} / \mathrm{ml})$ used [9].

In a study by Sahib et al. [11], the inhibitory effect was calculated according to the following equation:

Cell growth inhibition $(\%)=(1-(\mathrm{A} 0 / \mathrm{A})) \times 100$

Where,

A $0=$ the absorbance of the samples

$\mathrm{A}=$ the absorbance of the negative control

\subsection{High-performance Thin-layer Chromatography (HPTLC)}

Flavonoids and phenolic acids in the fraction were identified using HPTLC.

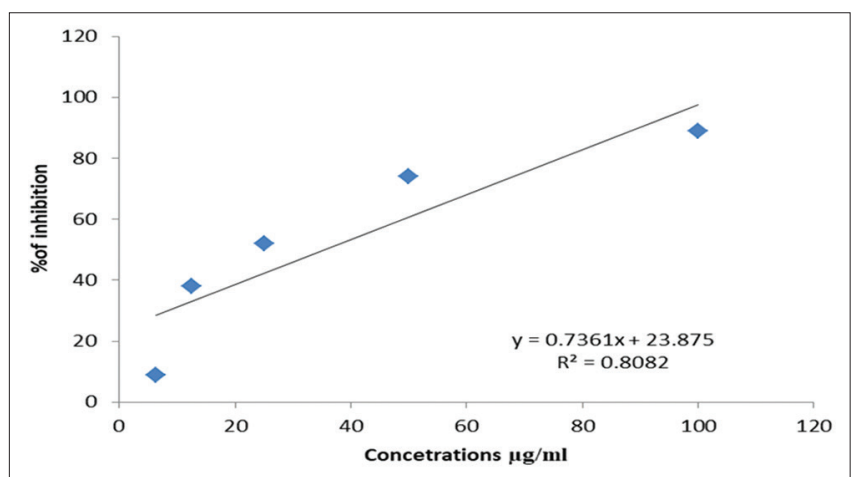

Figure 1: Antiproliferative activity of Althaea ludwigii against Michigan Cancer Foundation-7

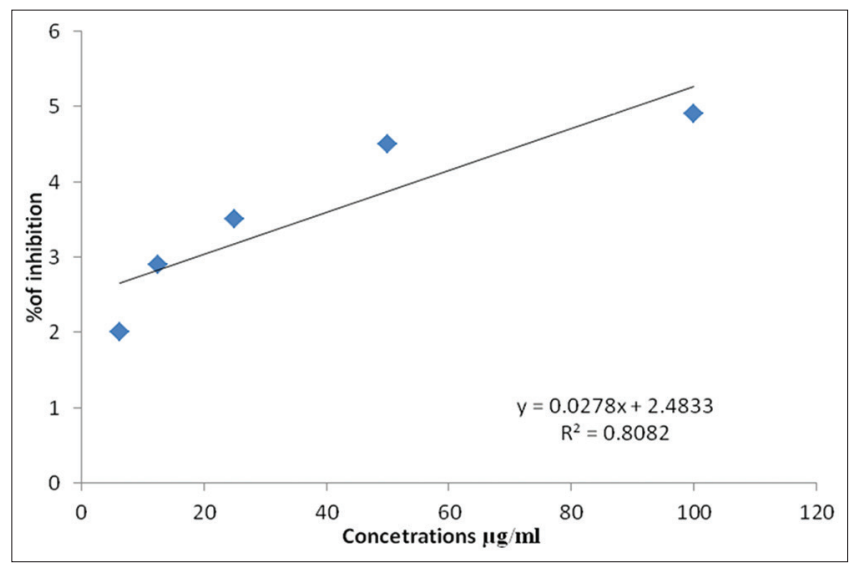

Figure 2: Antiproliferative activity of Althaea ludwigii against rate embryonic fibroblasts

\subsubsection{Chromatographic conditions}

Standard and sample solutions (rutin, quercetin, myricetin, kaempferol, silymarin, and ethyl acetate F.) $(5.0 \mu \mathrm{L}$ of each concentration $1 \mathrm{mg} /$ $\mathrm{mL}$ ) were applied to the plates $5 \mu \mathrm{L}$ each, using Camag Linomat $\mathrm{V}$ automatic sample applicator in the form of band (band length: $8 \mathrm{~mm}$ ) using microsyringe. The plates were saturated for $30 \mathrm{~min}$ in a twin trough glass chamber (for $10 \times 10 \mathrm{~cm}$ ) with the mobile phase of ethyl acetate:formic acid:acetic acid:water (100:11:11:27) subsequent to the development $[12,13]$. The plates were air dried and scanning (slit dimensions: $5 \times 0.45$ ) was performed at $254 \mathrm{~nm}$ and $366 \mathrm{~nm}$ using Camag TLC Scanner III.

\section{RESULTS AND DISCUSSION}

The results in Figure 1 showed that ethyl acetate fraction of A. ludwigii L. had significant antiproliferative activity against MCF-7 hormonal-dependent cancer cell line, the $\mathrm{IC}_{50}$ was $35.5 \mu \mathrm{g} /$ $\mathrm{mL}$. However, the results in Figure 2 showed that the $\mathrm{IC}_{50}$ was $1709.23 \mu \mathrm{g} / \mathrm{ml}$ on REF cell line which is normal cell line, the data may indicate that $A$. ludwigii L. may target the cancer cell only rather than cancer cell, this promising results may solve a big problem facing clinicians when they prescribing chemotherapy, as the chemotherapy killing both normal and cancer cells, it was important either to find an alternatives or to find an adjuvants agents which may help in reducing the chemotherapy dose and to act by mechanism(s) rather than the chemotherapy mechanisms [14]. The potential antiproliferative activity of $A$. ludwigii L. ethyl acetate fraction made sense to the researches to search for the bioactive constituents which may be responsible on the antiproliferative activity. Ethyl acetate fraction of the $A$. ludwigii L.

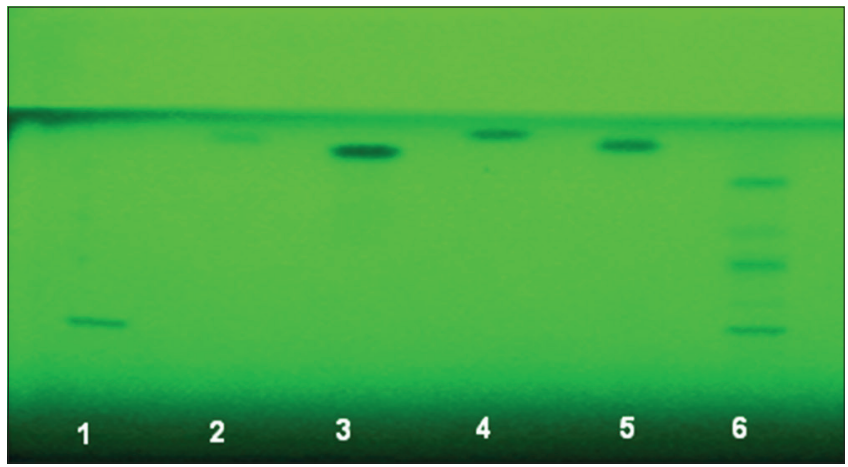

Figure 3: Chromatogram obtained from standards (1: Rutin, 2: Quercetin, 3: Myricetin, 4: Kaempferol, 5: Silymarin, and sample 6: Ethyl acetate F.).

Visualization was under UV light of wavelength $254 \mathrm{~nm}$

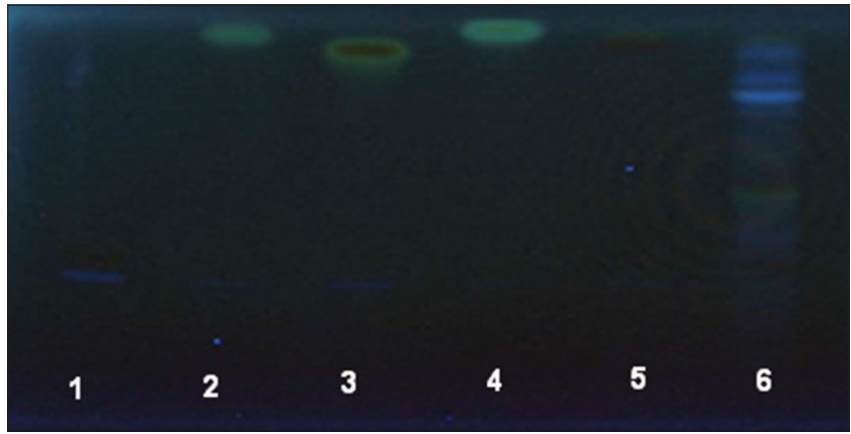

Figure 4: Chromatogram obtained from standards (1: Rutin, 2: Quercetin, 3: Myricetin, 4: Kaempferol, 5: Silymarin, and sample 6: Ethyl acetate F.). Visualization was under UV light of wavelength $366 \mathrm{~nm}$ 
extract was nominated to be investigated for the bioactive constituents using HPTLC; the results showed by Figures 3 and 4 that rutin has been identified in ethyl acetate fraction. A previous study done by Sahib et al., Chen et al. $[15,16]$ showed that rutin significantly inhibited the proliferation of LAN-5 cells line. Rutin had been approved that it induced G2/M arrest in the cell cycle progression and induced cell apoptosis. Moreover, rutin could decrease BCL2 expression and BCL2/ BAX ratio as well. In the meantime, the MYCN mRNA level and the secretion of tumor necrosis factor- $\alpha$ were inhibited [15]. In conclusion, these results suggest that rutin produces clear antiproliferative effects through encouraged G2/M arrest in the cell cycle development and induced cell apoptosis moreover, regulating the expression of the gene linked to apoptosis [15].

\section{CONCLUSION}

A. ludwigii L. extract may be has promising anti-breast cancer activity, with little effect on normal cells. The activity may related to the flavonoid exist in the extract.

\section{ACKNOWLEDGMENTS}

The authors would like to acknowledge the Iraq Biotech Cell Bank Unit, for providing laboratory facility.

\section{REFERENCES}

1. Kaileh M, Vanden BW, Boone E, Essawi T, Haegeman G. Screening of indigenous Palestinian medicinal plants for potential anti-inflammatory and cytotoxic activity. J Ethnopharmacol 2007;113:510-6.

2. Mehta RG, Murillo G, Naithani R, Peng X. Cancer chemoprevention by natural products: How far have we come? Pharm Res 2010; 27:950-61.

3. Soobrattee MA, Bahorun T, Aruoma OI. Chemopreventive actions of polyphenolic compounds in cancer. Biofactors 2006;27:19-35.

4. Dai J, Mumper RJ. Plant phenolics: Extraction, analysis and their antioxidant and anticancer properties. Molecules 2010;15:7313-52.

5. Fridlender M, Kapulnik Y, Koltai H. Plant derived substances with anti-cancer activity: From folklore to practice. Front Plant Sci 2015;6:799.
6. Tsao AS, Edward SK, Hong WK Chemoprevention of cancer. CA Cancer J Clin 2004;54:150-80.

7. Sallam AA, Hitotsuyanagi Y, Mansour ES, Ahmed AF, Gedara S, Fukaya $\mathrm{H}$, et al. Cucurbitacins from Bryonia cretica. Phytochem Lett 2010;3:117-21.

8. Maha N. Detection and isolation of flavonoids from Calendula officinallis (F. Asteraceae) cultivated in Iraq. Iraq J Pharm Sci 2016; 25:2.

9. Meerloo JV, Cloos J, Kaspers GJ. Cell sensitivity assays: The MTT assay. Methods Mol Biol 2011;731:237-45.

10. Al-Shammari AM, Alshami MA, Umran MA, Almukhtar AA, Yaseen NY, Raad K, et al. Establishment and characterization of a receptor-negative, hormone-nonresponsive breast cancer cell line from an Iraqi patient. Breast Cancer 2015;7:223.

11. Sahib HB, Ismail Z, Othman NH, Majid AM. Orthosiphon stamineus Benth. Methanolic extract enhances the anti-proliferative effects of tamoxifenonhumanhormonedependentbreastcancer.IntJPharm2009; 4:273-6.

12. Wagner H, Bladt S. Plant Drug Analysis. A Thin Layer Chromatography Atlas. Berlin: Springer; 2001.

13. Males Z, Plazibat M, Bilusiae V, Vundae ZI, Hazler KP. Thin-layer chromatographic analysis of flavonoids, phenolic acids, and amino acids in some Croatian hypericum Taxa. J Planar Chromatogr 2004; 7:280-5.

14. Abu-Raghif AR, Sahib HB, Hanoon MM. Anti-angiogenic activity of Zizyphus spinachristi leaves extracts. Int J Pharm Sci Rev Res 2015; 35:169-74.

15. Sahib HB, Al-Zubaidy AA, Jasim GA. Anti angiogenic activity of Vitex agnus castus methanol extract in vivo study. Iran J Pharm Sci 2016; 12:59-68.

16. Chen H, Miao Q, Geng M, Liu J, Hu Y, Tian L, et al. Anti-tumor effect of rutin on human neuroblastoma cell lines through inducing G2/M cell cycle arrest and promoting apoptosis. Sci World J 2013; 2013:165-269.

\footnotetext{
How to cite this article:

Alshaya ZEH, Kadhim EJ, Sahib HB. Antiproliferative activities of Althaea

ludwigii L. extract on Michigan Cancer Foundation-7 breast cancer cell

line. J App Biol Biotech. 2019;7(03):9-11. DOI: 10.7324/JABB.2019.70302
} 